\title{
MODEL INTERVENSI PEKERJA SOSIAL DALAM MENINGKATKAN KEBERFUNGSIAN SOSIAL LANSIA (Di Panti Sosial Tresna Werdha Minaula Kendari) \\ Sulfiah $^{1}$, Tanzil $^{2}$, dan Aryuni Salpiana Jabar ${ }^{3}$ Universitas Halu Oleo
}

\begin{abstract}
ABSTRAK
Penelitian dilakukan di Panti Sosial Tresna Werdha Minaula Kendari Desa Ranooha Kecamatan Ranomeeto Kabupaten Konawe Selatan. Tujuan penelitian untuk mengetahui model intervensi pekerja sosial dan faktor-faktor yang mempengaruhi keberhasilan intervensi pekerja sosial dalam meningkatkan keberfungsian sosial lansia di panti. Penelitian ini menggunakan metode deskriptif dengan pendekatan kualitatif, penentuan informan melalui Purposive Sampling, informan terdiri dari 5 orang pekerja sosial, 1 orang pembimbing psikologis, 1 orang perawat dan 3 orang lansia. Pengumpulan data menggunakan observasi, wawancara dan studi dokumentasi dan analisis data dilakukan dengan deskriptif kualitatif. Hasil penelitian ditemukan bahwa pekerja sosial dalam intervensinya terhadap lansia menggunakan dua model/bentuk yaitu direct practice (praktek langsung) dan indirect practice (praktek tidak langsung). Adapun faktor-faktor yang mempengaruhi keberhasilan intevensi pekerja sosial yaitu sikap klien yang kooperatif, kesadaran diri klien bahwa ia memiliki masalah dan kemauan untuk berubah, hubungan baik antara pekerja sosial dengan klien, dan penyesuaian materi, metode dan media dengan klien.
\end{abstract}

Kata Kunci: Intervensi; Lanjut Usia; dan Pekerja Sosial.

\section{PENDAHULUAN}

Pembangunan nasional dengan tujuan mewujudkan masyarakat adil dan makmur berdasarkan Pancasila dan Undang-Undang Dasar 1945, telah menghasilkan kondisi sosial masyarakat yang semakin membaik dan usia harapan hidup meningkat, sehingga jumlah lanjut usia bertambah. Walaupun banyak diantara lanjut usia yang masih produktif dan mampu berperan aktif dalam kehidupan bermasyarakat, berbangsa dan bernegara, namun karena faktor usianya akan banyak menghadapi keterbatasan sehingga memerlukan bantuan peningkatan kesejahteraan sosialnya.

Meningkatnya usia harapan hidup di Indonesia membuat jumlah penduduk berusia di atas 60 tahun, yaitu kelompok usia lanjut, semakin besar. Berdasarkan data Badan Pusat Statistik RI, 2015 usia harapan hidup di Indonesia sejak tahun 2014-2015 memperlihatkan adanya peningkatan dari usia 68,6 tahun menjadi 70,8 tahun dan proyeksi tahun 2030-2035 mencapai 72, 2 tahun. Presentase penduduk lansia di indonesia pada tahun 2015 sudah mencapai 8,5\%. Dengan lansia terlantar $15,8 \%$ (sekitar 2.851.606 jiw) dan rawan terlantar sebasar 25,82\% (4.652.280jiwa) (Kemenkes RI, 2016).

Proporsi penduduk lanjut usia (lansia) yang semakin besar membutuhkan perhatian dan perlakuan khusus dalam pelaksanaan pembangunan. Usia 60 tahun 


\section{WELVAART}

JURNAL ILMU KESEJAHTERAAN SOSIAL

ke atas merupakan tahap akhir dari proses penuaan yang memiliki dampak terhadap tiga aspek, yaitu biologis, ekonomi, dan sosial. Secara biologis, lansia akan mengalami proses penuaan secara terus menerus yang ditandai dengan penurunan daya tahan fisik dan rentan terhadap serangan penyakit. Secara ekonomi, umumnya lansia lebih dipandang sebagai beban daripada sumber daya. Secara sosial, kehidupan lansia sering dipersepsikan secara negatif, atau tidak banyak memberikan manfaat bagi keluarga dan masyarakat (BPS 2015).

Sesuai dengan pasal 1 ayat 2 Undang-undang No 13 tahun 1998 tentang kesejahteraan lanjut usia, lanjut usia adalah seseorang yang telah mencapai usia 60 (enam puluh) tahun keatas. Berbagai persolan-persoalan yang ditanggung bagi para lanjut usia, seperti penurunan kondisi fisik dan psikis, menurunnya penghasilan akibat pensiun, kesepian akibat di tinggal oleh pasangan atau teman seusianya, ditelantarkan oleh anaknya, atau lansia yang terlantar karena sudah tidak memiliki keluarga. Dengan banyaknya permasalahanpermasalahan yang dihadapi oleh penduduk lanjut usia pemerintah dan masyarakat telah berupaya melaksanakan kebijakan dan program untuk kesejahteraan lanjut usia dengan mendirikan panti-panti werdha, dengan tujuan agar para lansia yang terlantar masuk ke dalam panti werdha.

Menurut Departemen Sosial Republik Indonesia, Panti Werdha adalah suatu tempat untuk menampung lansia dan jompo terlantar dengan memberikan pelayanan sehingga mereka merasa aman, tentram dengan tiada perasaan gelisah maupun khawatir dalam menghadapi usia tua (Triwanti dkk, 2014). Demikian pula panti-panti tersebut didirikan baik ditingkat pusat maupun yang didirikan di daerah-daerah seperti pendirian Panti Sosial Tresna Werdha Minaula Kendari Provensi Sulawesi Tenggara.

Berdasarkan survei awal secara umum lansia yang ada dipanti merupakan lansia yang masuk dalam kategori lansia terlantar. jumlah lansia yang disantuni di Panti Sosial Tresna Werdha Minaula 95 orang yaitu lansia yang terlantar karena tidak mendapatkan pelayanan dan perhatian oleh keluarga, lansia yang terlantar karena tidak mempunyai keluarga, berasal dari keluarga miskin sehingga tidak mampu memenuhi kebutuhan dasar lansia, dan lansia yang tidak memiliki tempat tinggal ataupun yang tinggal sebatang kara.

Dalam perkembangannya, permasalahan lansia terlantar merupakan masalah yang membutuhkan penangan serius sehingga dibutuhkan panti werdha sebagai media rujukan intervensi. Intervensi terhadap klien lansia di panti dilakukan oleh perawat, psikolog, dan juga pekerja sosial. Masing-masing profesi tersebut memiliki peran yang berbeda-beda dalam penanganan klien lansia. Intervensi terhadap lansia dilakukan agar lansia dapat memenuhi kebutuhan dasar, melaksanakan tugas/peran sosial, mengatasi masalah serta mampu mengembangkan diri. Pelaksanaan intervensi lansia terlantar di panti werdha tidak terlepas dari peranan penting pekerja sosial.

Berdasarkan Undang-undang Nomor 11 Tahun 2009 pasal 1 ayat 4 pekerja sosial profesional adalah seseorang yang bekerja, baik di lembaga pemerintah maupun swasta yang memiliki kompetensi dan profesi pekerjaan sosial dan kepedulian dalam pekerjaan sosial yang diperoleh melalui 
pendidikan, pelatihan dan/atau pengalaman praktek pekerjaan sosial untuk melaksanakan tugas-tugas pelayanan dan penanganan masalah sosial.

Melihat dari berbagai persoalan dan permasalahan yang dialami lansia terlantar sehingga membutuhkan intervensi oleh pekerja sosial. Maka penulis merasa tertarik untuk mengkaji lebih mendalam bagaimana model intervensi pekerja sosial dan faktor apa yang mempengaruhi keberhasilan intervensi pekerja sosial dalam meningkatkan keberfungsian sosial lansia di Panti Sosial Tresna Werdha Minaula Kendari. Adapun tujuan dimaksudkan untuk mengetahui model intervensi yang digunakan pekerja sosial dalam meningkatkan keberfungsian sosial lansia serta untuk mengetahui faktor-faktor yang mempengaruhi keberhasilan intervensi pekerja sosial dalam meningkatkan keberfungsian lansia di Panti Sosial Tresna Werdha Minaula Kendari.

\section{METODE PENELITIAN}

Peneliti ini menggunakan metode deskriptif dengan pendekatan kualitatif untuk mendeskripsikan secara mendalam terkait fokus permasalahan penelitian. Pemilihan informan melalui Purposive sampling dengan pertimbangan bahwa informan tersebut mengetahui permasalahan dalam penelitian, informan berjumlah 10 orang diantaranya 5 orang pekerja sosial, 1 orang pembimbing psikologis, 1 orang perawat dan 3 orang lanjut usia. Data diperoleh melalui observasi, wawancara dan studi dokumentasi. Analisis data dilakukan secara deskriptif kualitatif, yakni data hasil penelitian diaolah dan disajikan dengan cara menggambarkan dan menafsirkan kategori-kategori yang relevan dengan penelitian.

\section{PEMBAHASAN}

Intervensi adalah tindakan spesifik oleh seorang pekerja sosial dalam kaitan dengan sistem atau proses manusia dalam rangka menimbulkan perubahan (Johnson, 2001). Seperti dijelaskan dalam hasil penelitian bahwa intervensi pekerja sosial dalam meningkatkan keberfungsian lansia di Panti Sosial Tresna Werdha Minaula Kendari menggunakan dua model/bentuk yaitu model praktek langsung (direct practice) dan praktek tidak langsung (indirect practice). Hal ini sejalan dengan teori Johnson bahwa dalam pelaksanaannya, intervensi dibagi dalam dua bentuk yaitu direct practice (praktek langsung) dan indirect practice (praktek tidak langsung),

1. Praktek langsung (direct practice) yaitu intervensi yang langsung bersangkutan dengan para individu, keluarga-keluarga, dan kelompokkelompok kecil yang memfokuskan pada perubahan baik transaksi dalam keluarga, sistem kelompok kecil atau individu dan fungsi kelompok-kelompok kecil dalam hubungan dengan orang-orang dan institusi kemasyarakatan dalam lingkungan mereka.

Dalam praktek langsung, intervensi pekerja sosial dilakukan secara langsung bersama-sama dengan lanjut usia dalam suatu kegiatan untuk membantu lansia meningkatkan keberfungsian sosialnya. Adapun kegiatan yang dilakukan dalam bentuk praktek langsung pekerja sosial diantaranya: 


\section{WELVAART}

\section{JURNAL ILMU KESEJAHTERAAN SOSIAL}

a. Melakukan assessment

Assessment merupakan penilaian atau penafsiran terhadap situasi dan orang-orang yang terlibat didalamnya (Sukoco,199). Kegiatan assessment yang dilakukan kepada lanjut usia merupakan bentuk praktek langsung, dimana pekerja sosial secara langsung bertemu dengan lansia untuk bersama-sama mengungkap permasalahan, kebutuhan dan potensi lansia. Pekerja sosial melakukan assessment pada tahap seleksi untuk memperoleh informasi mengenai masalah, kebutuhan, potensi dan data diri lansia untuk menentukan apakah klien lanjut usia memenuhi syarat untuk mendapatkan pelayanan di panti. Selain itu assessment juga dilakukan dalam penyelesaian masalah lansia yang berkonflik dalam hal ini pekerja sosial bertemu langsung dengan lansia untuk mengungkap faktor penyebab permasalahan agar masalah lansia dapat diselesaikan.

b. Bimbingan fisik

Bimbingan fisik yang diberikan kepada lanjut usia berupa kegiatan untuk memelihara tubuh lansia agar tetap bugar dengan memberikan kegiatan-kegiatan yang sesuai dengan kemampuan lansia, pelaksanaan bimbingan fisik kepada lansia dilakukan oleh pekerja sosial dengan menggunakan model praktek langsung. Pekerja sosial membimbing lansia dalam melakukan senam dan lulo bersama pada hari jumat dan senam otak pada hari kamis kegiatan ini membuat tubuh lansia tetap bugar sehingga lansia mampu melakukan aktifitas-aktifitasnya dengan baik.

c. Bimbingan keterampilan

Bimbingan keterampilan kepada lansia yang ada di Panti Sosial Tresna Werdha Minaula Kendari merupakan suatu kegiatan memberikan keterampilan kepada lansia sesuai minat, bakat dan kemampuannya. Kegiatan bimbingan keterampilan kepada lansia merupakan intervensi pekerja sosial dalam bentuk praktek langsung, dengan membimbing lansia membuat kerajinan tangan agar lansia memiliki aktivitas untuk mengisi waktu luang sehingga ia tidak merasa bosan. Selain itu dengan keterampilan yang dimiliki lanjut usia menjadi lebih produktif.

d. Bimbingan sosial

Bimbingan sosial merupakan suatu kegiatan yang dilakukan pekerja sosial untuk membimbing, memberikan arahan-arahan dalam meningkatkan kemampuan, motivasi dan perananya dalam rangka memperkuat keberfungsian sosial lansia. pekerja sosial dalam melakukan bimbingan sosial kepada lansia menggunkan bentuk praktek langsung yang dilakukan untuk membimbing dan memberikan arahan-arahan kepada lansia agar menjaga hubungan baik antar sesama lansia, menjaga kebersihan tubuh dengan mandi dan menjaga kebersihan lingkungan dengan tidak menghambur-hamburkan kotoran. Selain itu dilakukan pula bimbingan sosial kelompok kepada lansia berupa permainan-permainan dan bernyanyi untuk menguragi kejenuhan, meningkatkan kebersamaan dan interaksi sosial antar lansia, menghibur para lansia dan meningkatkan daya motorik lansia. kegiatan ini dipandu langsung oleh pekerja sosial. 
2. Praktek tidak langsung (indirect practice) yaitu bentuk intervensi yang dilakukan pekerja sosial dengan berkolaborasi dengan pihak lembaga ataupun profesi lain dan semata-mata untuk menolong klien (Johnson, 2001). Intervensi pekerja sosial dalam bentuk praktek tidak langsung kepada lansia yang ada di Panti Sosial Tresna Werdha Minaula Kendari dalam pelaksanaannya dilakukan untuk menolong lansia yang membutuhkan penanganan oleh profesi lain maupun lembaga yang dapat memberikan bantuan yang dibutuhkan. Kegiatan-kegiatan yang dilakukan pekerja sosial dalam bentuk praktek tidak langsung diantara:

a. Menghubungkan lansia dengan sistem sumber yang dibutuhkan

Intervensi pekerja sosial dalam bentuk praktek tidak langsug dilakukan dengan bekerjasama dengan perawat atau dokter untuk melakukan cek kesehatan dan penanganan lansia yang sakit, fisioterapis, psikologi dan rumah sakit jiwa untuk penangan lansia yang mengalami penurunan fungsi sosial dan mengalami degradasi mental. Dalam hal ini pekerja sosial menghubungkan lansia dengan sistem sumber tersebut agar lansia mendapatkan penangan yang tepat.

b. Menfasilitasi lansia

Intervensi pekerja sosial dalam bentuk praktek tidak langsung dilakukan dengan mengfasilitasi atau memungkinkan lansia untuk mendapatkan apa yang menjadi kebutuhannya, seperti menghadirkan ustad ke panti untuk memberikan bimbingan agama kepada lansia, memberikan ceramah, pengajian dan sholat berjamaah. Selain itu pekerja sosial bekerja sama dengan perawat dalam penangan lansia yang sakit dalam hal ini pekerja sosial dalam intervensinya menfasilitasi lansia untuk mendapatkan jaminan kesehatan.

c. Mengalihkan/merujuk lansia

Intervensi pekerja sosial dalam bentuk praktek tidak langsung dilkukan dengan merujuk lansia kepada suatu lembaga atau profesi yang dapat memberikan penangan lebih lanjut. Rujukan diberikan kepada lansia yang mengalami sakit parah untuk mendapatkan penanganan oleh pihak rumah sakit yang telah bekerjasama dengan pekerja sosial.

d. Mendampingi lansia

Intervensi pekerja sosial dalam bentuk praktek tidak langsung dilakukan dengan mendampingi lansia dalam aktivitas-aktivitasnya dengan pihak lembaga maupun profesi-profesi lain. Pendampingan dilakukan saat lansia mendapatkan pelayanan oleh pihak salon untuk melakukan perawatan, keramas dan potong rambut, pendampingan saat lansia mendapatkan penanganan oleh pihak rumah sakit maupun saat lansia mengalami masalah dan membutuhkan pelayanan.

Adanya berbagai kegiatan-kegiatan bimbingan, pendampingan dan lainnya yang dilakukan oleh pekerja sosial di Panti Sosial Tresna Werdha minaula Kendari baik dalam bentuk praktek langsung maupun dalam bentuk praktek tidak langsung akan membantu lansia untuk meningkatkan keberfungsian sosialnya. 


\section{WELVAART}

JURNAL ILMU KESEJAHTERAAN SOSIAL

Keberhasilan intervensi pekerja sosial dalam meningkatkan keberfungsian lansia yang ada di Panti Sosial Tresna Werdha Minaula Kendari dipengaruhi oleh beberapa faktor diantaranya:

1. Sikap klien yang kooperatif dalam menjalani intervensi

Sikap kooperatif yaitu sikap yang menunjukan kerjasama dan tidak melakukan penentangan. Reaksi yang ditunjukan klien/lansia akan mempengaruhi berhasil atau tidaknya proses intervensi yang dilakukan pekerja sosial. klien yang memiliki sikap kooperatif akan terbuka dalam mengungkapkan masalahnya dan menerima keberadaan pekerja sosial sehingga memudahkan pekerja sosial dalam mendapatkan informasi tentang klien, selain itu klien yang kooperatif proaktif dalam mengikuti proses intervensi serta mematuhi aturan-aturan dan prosedur dalam pelaksanaan intervensi, sehingga sikap kerja sama dari klien akan sangat mempengaruhi keberhasilan intervensi.

2. Kesadaran diri klien bahwa ia memiliki masalah dan kemauan untuk berubah

Klien yang sadar akan masalahnya dan memiliki kemauan untuk berubah maka akan mengikuti masukan-masukan dan proses intervensi dengan baik, dengan adanya kesadaran akan pentingnya memiliki teman dari klien lansia yang memiliki kebiasaan bertengkar dengan temannya akan memudahkan pekerja sosial dalam penyelesaian masalahnya. Namun tanpa adanya kesadaran diri dari klien, maka klien akan mengabaikan apa yang anjurkan oleh pekerja sosial, seperti mengabaikan arahan-arahan pekerja sosial untuk membersihkan maupun menjaga kebersihan tubuh dengan mandi secara teratur bagi lansia yang malas mandi. Sehingga kesadaran diri dan kemauan untuk berubah dari klien merupakan salah satu faktor yang mempengaruhi keberhasilan intervensi.

3. Hubungan baik yang telah dibangun antara peksos dengan klien sebelum pelaksanaan intervensi.

Kesinambungan interaksi antara pekerja sosial dengan klien akan memudahkan proses intervensi, dengan terjalinya hubungan yang baik maka klien akan percaya, dan terbukaan kepada pekerja sosial dengan kondisi semacam itu maka dapat tercipta relasi pertolongan, dan segala informasi yang akurat akan dapat diperoleh dengan mudah. Namun hubungan tersebut sebatas hubungan profesional tidak sampai menimbulkan hubungan emosional yang lebih karena dapat menimbulkan ketergantungan klien kepada pekerja sosial.

4. Penyesuaian Materi, Metode dan Media dengan Klien

Pemberian materi yang menarik dan disukai oleh klien akan mempengaruhi keberhasilan intervensi namun apabilah materi yang diberikan terlalu sering dan berulang-ulang akan membuat klien bosan, jenuh dan malas mengikuti proses intervensi, begitu halnya dengan penggunaan metode dan media harus disesuaikan agar klien merasa nyaman. Meteri, metode maupun media yang gunakan harus dikreasikan seperti dilakukan lewat media permainan, bernyanyi dalam pelaksanaannya harus disesuaikan dengan mood klien dan dilakukan dengan cara yang tidak terlalu serius. Kesalahan dalam 


\section{WELVAART}

\section{JURNAL ILMU KESEJAHTERAAN SOSIAL}

memilih materi, metode dan media dapat mengakibatkan kegagalan intervensi yang dilakukan.

Dari hasil tersebut dapat dibuat suatu tipologi faktor-faktor yang mempengaruhi keberhasilan intervensi diantaranya, faktor internal yaitu faktor yang berasal dari dalam diri klien, yakni sikap klien yang kooperatif dalam menjalani intervensi dan kesadaran diri dari klien bahwa ia memiliki masalah dan memiliki keinginan untuk berubah. Selain itu terdapat pula faktor external yaitu faktor yang berasal dari luar diri klien, yakni hubungan baik yang telah dibangun antara pekerja sosial dengan klien sebelum pelaksanaan intervensi dan penyesuian materi, metode dan media dengan klien.

\section{PENUTUP}

Berdasarkan pembahasan diatas bahwa pekerja sosial dalam intervensinya terhadap lansia yang ada di Panti Sosial Tresna Werdha Minaula Kendari menggunakan dua model yaitu model praktek langsung (direct practice) dan praktek tidak langsung (indirect practice).

Model praktik langsung yaitu intervensi yang langsung bersangkutan dengan klien lanjut usia, dimana kegiatan maupun penyelesaian masalah ditangani langsung oleh pekerja sosial seperti: melakukan assessment pada tahap seleksi untuk mengetahui permasalahan, kebutuhan dan potensi lansia, memberikan bimbingan fisik untuk meningkatkan maupun memelihara kebugaran tubuh lansia dengan melakukan senam dan lulo, memberikan bimbingan keterampilan untuk mengembangkan minat, bakat dan potensi lansia seperti membuat kerajinan tangan, memberikan bimbingan sosial dengan memeberikan masukan-masukan dan arahan-arahan kepada lanjut usia serta bimbingan sosial kelompok dengan media bermain dan bernyanyi dan menyelesaian masalah lansia yang berkonflik.

Model Praktek tidak langsung yaitu bentuk intervensi yang dilakukan pekerja sosial dengan berkolaborasi dengan pihak lembaga ataupun profesi lain. Intervensi pekerja sosial dalam praktek tidak langsung dilakukan dengan menghubungkan klien dengan sistem sumber (instansi/profesi) yang dapat memberikan bantuan yang dibutuhkan seperti menghubungkan lansia keperawat, dokter, dan pembimbing psikologis, menfasilitasi lansia dalam mendapatkan pelayanan dan bimbingan, mengalihkan/merujuk klien lansia ke instansi/profesi yang dapat memberikan penanganan lebih lanjut seperti merujuk lansia kerumah sakit, mendampingi lanjut usia saat melakukan kegiatan dengan profesi lain maupun saat mengalami masalah.

Faktor-faktor yang mempengaruhi keberhasilan intervensi pekerja sosial dalam meningkatkan keberfungsian lansia di Panti Sosial Tresna Werda Minaula Kendari diantaranya : 1). sikap klien yang kooperatif dalam menjalani intervensi yakni kemauan bekerjasama dengan baik yang ditunjukan dengan penerimaan dan keterbukaan klien pekerja sosial dalam memberikan informasi, proaktif dan mematuhi aturan dan prosedur dalam proses intervensi. 2). Kesadaran diri klien bahwa ia memiliki masalah dan kemauan untuk berubah, faktor ini akan sangat mempengaruhi keberhasilan intervensi, karena klien yang sadar akan masalahnya akan terdorong untuk berperan serta dalam berbagai kegiatan yang diberikan dan 
menjalankan arahan-arahan dari pekerja sosial. 3) Hubungan baik yang telah dibangun antara pekerja sosial dengan klien sebelum pelaksanaan intervensi akan menimbulkan kepercayaan dan keterbukaan klien dalam memberikan informasi yang benar sehingga pekerja sosial tidak salah dalam memberikan intervensi sehingga akan sangat mempengaruhi keberhasilan intervensi. 4) Penyesuaian materi, metode dan media dengan klien merupakan faktor yang mempengaruhi keberhasilan intervensi pekerja sosial. Pemberian materi maupun penggunaan metode dan pemilihan media yang disukai klien lansia seperti permainan, bernyanyi akan sangat efektif. Namun Kesalahan dalam memilih materi, metode dan media dapat mengakibatkan kegagalan intervensi yang dilakukan.

Berdasarkan hasil penelitian yang telah dilakukan, ada beberapa point yang menjadi saran dari peneliti, saran tersebut antara lain : Pekerja sosial diharapkan lebih fokus pada penanganan lansia, melihat ada beberapa pekerja sosial yang memiliki spesifikasi tugas yang double sehingga tidak memiliki cukup waktu untuk penanganan lansia. Kegiatan-kegiatan yang telah dijadwalkan diharapkan dapat dilaksanakan secara rutin, sehingga dapat meningkatkan keberfungsian sosial lansia yang ada di panti serta pemerintah harus tetap mendukung adanya pendirian panti karena dengan didirikanya panti para jompo terlantar dapat memperoleh pelayanan sehingga mereka merasa aman, tentram dengan tiada perasaan gelisah maupun khawatir dalam menghadapi usia tua.

\section{DAFTAR PUSTAKA}

Badan Pusat Statistik. 2015. Statistik Penduduk Lanjut Usia 2014. Jakarta

Johnson, Louise C. 2001. Praktek Pekerjaan Sosial (Suatu Pendekatan Generalist). Bandung: terj. Tim Penerjemah STKS

Kemenkes RI. 2016. Situasi Lanjut Usia (Lansia) di Indonesia.http://www.depkes .go.id/resources/download/pusdatin/infodatin/infodatin\%20lansia\%202016 .pdf diakses 26 oktober 2016

Sukoco Dwi Heru. 1991. Profesi Pekerjaan Sosial dan Proses Pertolongan. Bandung: Kopma Stks

Triwanti Shinta Puji, Ishartono dan Arie.S.G. 2014. Peran Panti Sosial Tresna Werdha Dalam Upaya Meningkatkan Kejejahteraan Lansia. Social Work Journal, Vol 4 No 2 (29-136) 